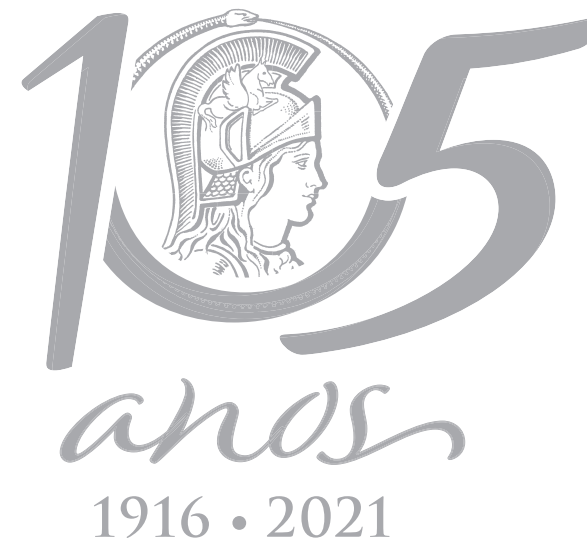

$1916 \cdot 2021$

\title{
ECOSYSTEMS
}

\section{Geographic patterns of skull variation in two species of cavies of the genus Microcavia (Rodentia, caviidae)}

\author{
SOFÍA d' HIRIART, PABLO TETA \& GERARDO R. CUETO
}

\begin{abstract}
We study the geographical variation of the skull in the cavies Microcavia australis and M. maenas and its association with environmental variables. We tested four hypotheses previously proposed to explain the geographic patterns of morphological variation i) heat conservation; ii) heat dissipation; iii) primary productivity and iv) seasonality. We used 16 cranial measurements taken from 180 individuals. We analyzed the spatial variation in cranial morphology through Generalized Additive Models. Both species showed a north-south clinal gradient in skull size (increasing towards colder, less seasonal environments, with lower summer rainfalls in $M$. australis and towards warmer and seasonal environments in M. maenas). Microcavia australis presented greater ecomorphological variability than $M$. maenas, in agreement with its wider distribution and occurrence in more diverse environments. Also, the length of tympanic bullae in M. australis was larger towards its northern distributional range (associated to smaller skulls), and smaller to the south (associated to larger skulls). Overall, the distributional range of both species coincided with unproductive environments, where temperature represents a limiting factor and, together with rainfall, might determine the observed morphological patterns.
\end{abstract}

Key words: Cavioidea, cranial morphology, environmental predictors, geographical variation, spatial patterns.

\section{INTRODUCTION}

The association between mammal body size and the variation in environmental conditions has been largely analyzed (e.g., Rosenzweig 1968a, Brown \& Lee 1969, McNab 1971, Boyce 1978, Kennedy \& Lindsay 1984, Ralls \& Harvey 1985, Ritke \& Kennedy 1988, Owen 1989, Sikes \& Kennedy 1992). However, although several studies have partially addressed the causes of the geographic patterns associated to morphological change, the geographic structure of phenotypic variation in several widely distributed species remains unclear (Monteiro et al. 2003, Alvarado-Serrano et al. 2013, Maestri et al. 2016).
According to Endler (1983) and Thorpe (1984), the causes of geographic variation can be divided in two large groups: i) historic processes, or phylogeny; and ii) current ecological processes. Geographic variation due to historic processes or phylogeny might be a consequence of both past climate and/ or geological events (Perez \& Monteiro 2008, Perez et al. 2010, Martínez et al. 2013, GarcíaMendoza et al. 2018). At the same time, variation due to current ecological processes results from the balance between gene flow and natural selection derived from biological conditions (e.g., interspecific competitions) or physics (e.g., adaptation to climate conditions) (Thorpe 1987). In this context, four hypotheses to explain 
both the adaptations of different species to the prevailing environmental conditions and the patterns of corporal size geographic variation (Wigginton \& Dobson 1999) were proposed. The first hypothesis (heat conservation) suggests that, within an endotherm animal species, individuals with greater corporal size occupy colder environments than those of smaller size (Bergmann 1847). Thus, the smaller surface/ volume relationship of larger individuals serves to conserve heat in colder environments (James 1970, McNab 1971, 2002, 2010). Such hypothesis has been traditionally related to Rensch (1938), and to the intraspecific formulation of the Bergmann's rule (Mayr 1956, 1963), which establishes that corporal size increase in a given species is related to temperature decrease (Bergmann 1847). James (1970, 1991), and Aldrich \& James (1991) suggested that the combination of certain climatic variables, such as humidity and temperature, are better predictors of corporal size intraspecific variation of endothermic animals. In this way, they suggested that small-sized individuals would be more closely associated with warm and wet conditions, while larger individuals would be associated with colder, drier conditions. Thus, a second hypothesis relies on heat dissipation, establishing that the greatest surface/volume relationship of smaller individuals helps to dissipate heat in warm environments. On the other hand, since corporal size is be maintained by food supply, natural selection should adapt species to various energy flows, modifying their corporal size in according to environmental productivity (Rosenzweig 1968a, Wigginton \& Dobson 1999). In this way, a third hypothesis (productivity) predicts a different relationship to the Bergmann's rule, since temperature and productivity do not necessarily show a positive relationship. In turn, real evapotranspiration is a significant predictor of primary productivity
(Rosenzweig 1968b). Finally, one of the most important aspects of seasonal environments is the variation in essential resource availability (e.g., food, water, nutrients or energy, Boyce 1979, Gür 2010). In this context, a fourth hypothesis (seasonality) suggest that corporal size tends to increase in areas with great seasonality in food abundance and energy demand (Boyce 1978, Lindstedt \& Boyce 1985, Millar \& Hickling 1990, Dunbrack \& Ramsay 1993).

Within the anatomical structures that vary or are influenced by environmental variables, the skull is one to the most labile and thus prone to be influenced by environmental variations. Several studies have evaluated the geographic variation in rodent size and shape using quantitative cranial characters (Hoffmeister 1951, Schmidly 1973, Bradley et al. 1996, Maestri et al. 2016, Teta et al. 2017), or a combination of cranial characters and genetic data (OrdóñezGarza et al. 2010, Ávila-Valle et al. 2012, Lorenzo et al. 2016). Such studies show that the spatial variations of anatomical features allow a greater understanding of the degree to which different phenotypes respond to local environmental pressures. Further, they might also contribute to conservation management strategies (McGuire 2010).

The genus Microcavia exhibits a wide ecomorphological diversity which encompasses high environmental diversity through its wide geographical distribution (Teta et al. 2017). Based on morphological evidence, Teta et al. (2017) demonstrated that Microcavia australis is a species complex formed by at least three different taxa: M. australis s.S., M. maenas and the recently described $M$. jayat. Microcavia australis s.s. is widely distributed in the highlands of central-western Argentina and the Patagonian steppes to the south, reaching the northern border of the Strait of Magellan in Argentina and Chile; $M$. maenas ranges along montane and 
hilly areas of central-western Argentina; and $M$. jayat is restricted to the Dry Chaco ecoregion of north-central Argentina.

The main objective of our study is to analyze the cranial morphological variation in M. australis and M. maenas throughout their whole distributional ranges, to determine how such variability is geographically structured. For that, we evaluate the four hypotheses discussed above (see also Wigginton \& Dobson 1999), namely: i) heat conservation; ii) heat dissipation; iii) primary productivity and iv) seasonality. We expect that $M$. australis, with a wider geographical distribution and occupancy of more heterogeneous environments, will exhibit greater ecomorphological variation than M. maenas, which is more geographically restricted.

\section{MATERIALS AND METHODS}

\section{Examined materials}

The examined specimens are housed in the following museums and biological collections: Museo Argentino de Ciencias Naturales "Bernardino Rivadavia" (Buenos Aires, Argentina); Colección de Mamíferos Lillo (Tucumán, Argentina); Colección de Mamíferos del Instituto Argentino de Investigación de Zonas Áridas (Mendoza, Argentina); Colección Elio Massoia (acquired by the Fundación de Historia Natural Félix de Azara, Buenos Aires, Argentina); Colección de Mamíferos del Centro Nacional Patagónico (Chubut, Argentina); Colección de Mamíferos de la Universidad Austral de Chile (Valdivia, Chile); American Museum of Natural History (New York, EEUU); Field Museum Natural History (Chicago, EEUU); United States Natural Museum (Washington, EEUU). 180 adult specimens of the genus Microcavia, of which 78 corresponds to $M$. australis and 102 to M. maenas (see Appendix A for a complete list) were examined.

\section{Morphometric data}

For each specimen, the following sixteen craniodental measurements were recorded using a digital calliper to the nearest $0.01 \mathrm{~mm}$ (Figure S1 - Supplementary Material): total length of the skull (TLS); condylo-incisive length (CIL); interorbital constriction (IOC); greatest zygomatic breadth (ZB); breadth of braincase $(\mathrm{BB})$; length of nasals (NL); width of nasals $(\mathrm{NW})$; length of frontals (FL); length of the upper diastema (DL); length of incisive foramina (LIF); breadth of incisive foramina (BIF); length of upper toothrow (TRL); palatal length ( $\mathrm{PL}$ ); breadth of palate at the level of the upper third molar (BPM3); breadth across the paraoccipital processes (BPP); and length of tympanic bullae (TBL). Cranial measurements were taken following Contreras \& Contreras (1984), and Ubilla \& Rinderknecht (2014).

\section{Environmental variables}

The studied specimens come from 32 localities in the case of $M$. australis and 28 in the case of $M$. maenas (Figure 1, Appendix B). The geographical coordinates were taken from specimen tags, and when unavailable, from Google Earth ver. 7.3.2 (Google Inc. 2018).

For each sampling location, climatic variables such as mean annual temperature (BIO1), temperature seasonality (BIO4), mean annual precipitation (BIO12), and precipitation seasonality (BIO15) were obtained from the WorldClim database (see Table I, Hijmans et al. 2005). Topographic variables (altitude and standard deviation of the altitude) were obtained from the GTOPO30 digital elevation model, within a 3-km radius circle around each location. Also, at each locality an indirect measure of humidity was obtained, through the division of annual precipitation by annual mean temperature (P/T, see García 1988, García-Mendoza et al. 2018). Finally, net primary productivity (NPP) for 
November 2016 at a $0.1^{\circ}$ resolution (expressed as $\mathrm{gCm}^{-2}$ days $^{-1}$, where $\mathrm{gC}=$ grams of Carbon), was obtained from the NASA Earth Observation site (NEO 2017). Data layers were processed using ArcGIS ver.10.5 (ESRI 2016).

\section{Statistical analyses}

To analyze the influence of the cranial measurements on the morphological variation of the skull of $M$. australis and $M$. maenas a Principal Components Analysis (PCA) was used. Also, since environmental variables are usually associated, correlation analyses among the environmental variables were carried out.

The geometric mean of all the (previously log-transformed) skull variables was computed as a proxy of the skull overall size (MeachenSamuels \& Van Valkenburgh 2009). To evaluate skull shape variation, we divided each variable

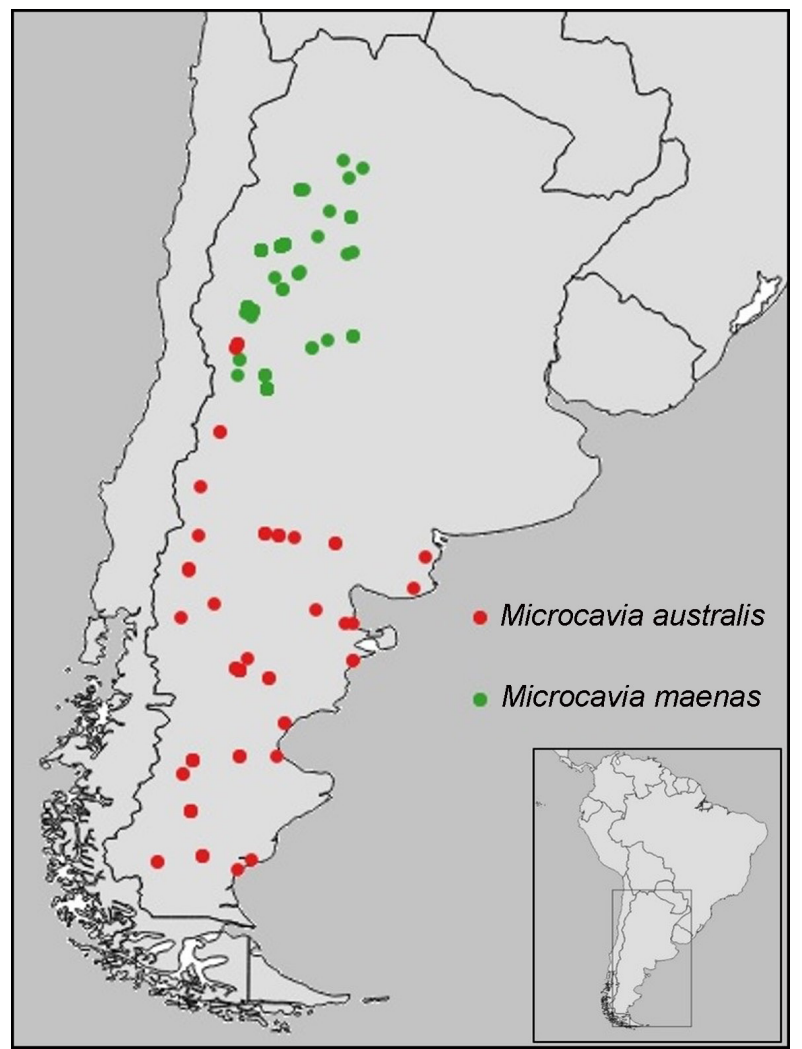

Figure 1. Collecting localities for Microcavia australis (red dots) and M. maenas (green dots) in Argentina. by the geometric mean to convert them in shape variables (Mosimann 1970). Spatial variations in the skull shape and size for both species were evaluated through Generalized Additive Mixed Models (GAMM) (Wood 2017). GAMM models provide a broad and flexible framework for regression analyses in realistically complex situations, as those involving longitudinal and spatial data (Lang \& Fagrmeir 2001). To detect spatial patterns of the skull shape throughout the geographic space, a nonlinear interaction (tensor product) between latitude and longitude was included (Wood 2017). To identify environmental predictors of the skull size and shape, a second GAMM was carried out for each species, with climatic and topographic variables as predictors. Cubic splines (Wood 2017) for all the environmental variables were included to assess linear and nonlinear trends of the skull size. The Akaike's information criterion (AIC) was used to select among alternative candidate models. Finally, a variable called "locality" was included as a random effect in all models, to account for the non-independence among measures of individuals collected in the same locality.

The PCA analysis was performed with PAST 3.16 (Hammer et al. 2001). Both the correlation analysis and the GAMM, were carried out using the corrplot (Wei \& Simko 2016) and mgcv packages (Wood 2016), respectively, in R software (R Core Team 2017).

\section{RESULTS}

Changes in skull shape were not significant for neither of the studied species, for which the results are not shown; only the results regarding skull size are reported. 
Table I. Environmental variables used in the analyses, with indication of thematic layer, source, classification system and resolution.

\begin{tabular}{|c|c|c|c|c|}
\hline & Thematic layer & Source & Classification system & Resolution \\
\hline \multirow[t]{4}{*}{ Climatic variables } & $\begin{array}{l}\text { Annual mean } \\
\text { temperature (Bio 1) }\end{array}$ & Worldclim & $\begin{array}{l}\text { Interpolation of } \\
\text { global data }\end{array}$ & 30 seconds \\
\hline & $\begin{array}{l}\text { Temperature seasonality } \\
\text { (DS) (Bio 4) }\end{array}$ & (Hijmans et al. 2005) & & $\left(\sim 1 \mathrm{~km}^{2}\right)$ \\
\hline & $\begin{array}{l}\text { Annual precipitation (Bio } \\
12 \text { ) }\end{array}$ & & & \\
\hline & $\begin{array}{c}\text { Precipitation seasonality } \\
\text { (VC) (Bio 15) }\end{array}$ & & & \\
\hline \multirow[t]{2}{*}{ Topographic variables } & Height & GTOPO 30 & & 30 seconds \\
\hline & Height SD (Hsd) & USGS (1996) & & $\left(\sim 1 \mathrm{~km}^{2}\right)$ \\
\hline \multirow[t]{2}{*}{ Other variables } & Humidity $(\mathrm{P} / \mathrm{T})$ & García 1988 & $\begin{array}{l}\text { Interpolation of } \\
\text { global data }\end{array}$ & \\
\hline & $\begin{array}{c}\text { Net Primary Productivity } \\
\text { (PPN) }\end{array}$ & $\begin{array}{l}\text { NASA Earth } \\
\text { Observations }\end{array}$ & & $0.1^{\circ}$ resolution \\
\hline
\end{tabular}

\section{Principal Components Analysis (PCA)}

In Microcavia australis, the first two Principal Components (PC) explained $86 \%$ and $3 \%$ of the total variability, respectively (Table II, Figure S2). Most of the morphological variables were associated with the first PC, showing a certain relationship with cranial size variations. However, the length of tympanic bullae (TBL), and to a lesser extent, the length of nasals (NL), and the condylo-incisive length $(\mathrm{CIL})$ showed a different behaviour to the rest of morphological variables, being associated with the PC2 and showing a certain independence regarding size. In Microcavia maenas, PC1 explained $72 \%$ of the total variability, while PC2 explained 5\% (Table II, Figure S2). Thus for M. maenas, the observed morphological changes correspond almost entirely to variations in overall cranial size. In both species, a size gradient was observed, in which individuals with larger skulls were found towards the positive side of PC1, while those with smaller skulls were found towards the negative side of this component.

\section{Environmental variables correlation}

Throughout the distributional range of $M$. australis, latitude was positively correlated with several environmental variables (Figure S3), while longitude was positively correlated with NPP and annual temperature (BIO1), and negatively correlated with altitude and seasonality precipitation (BI015). NPP showed a positive correlation with both temperature variables (BIO1 and BIO4), while humidity was correlated with both precipitation variables (BIO12 and BI015). The topographic and temperature variables were correlated among each other; i.e., altitude was positively correlated with its standard deviation, and BIO1 was positively correlated with $\mathrm{BIO}$. Environmental variables that were negative correlated included altitude with both temperature variables ( $\mathrm{BIO} 1$ and $\mathrm{BIO4}$ ), altitude standard deviation with $\mathrm{BIO} 4$, and humidity with BIO1.

In the geographical space occupied by $M$. maenas, latitude and longitude were negatively correlated with both temperature variables 
Table II. Results of the principal components analysis performed with 16 morphological variables of Microcavia australis and M. maenas specimens. See Materials and Methods for explanation of variable abbreviations.

\begin{tabular}{|c|c|c|c|c|}
\hline & \multicolumn{2}{|c|}{$\begin{array}{c}\text { Microcavia } \\
\text { australis }\end{array}$} & \multicolumn{2}{|c|}{$\begin{array}{c}\text { Microcavia } \\
\text { maenas }\end{array}$} \\
\hline & PC 1 & PC 2 & PC 1 & PC 2 \\
\hline TLS & 0.556 & 0.097 & 0.533 & -0.265 \\
\hline CIL & 0.553 & 0.095 & 0.552 & -0.289 \\
\hline IOC & 0.073 & 0.276 & 0.085 & 0.195 \\
\hline ZB & 0.277 & -0.313 & 0.319 & 0.639 \\
\hline BB & 0.100 & -0.063 & 0.143 & 0.253 \\
\hline NL & 0.225 & 0.323 & 0.257 & 0.133 \\
\hline NW & 0.064 & 0.043 & 0.079 & 0.197 \\
\hline FL & 0.172 & -0.089 & 0.141 & -0.214 \\
\hline DL & 0.176 & -0.017 & 0.196 & -0.131 \\
\hline LIF & 0.053 & -0.028 & 0.009 & 0.015 \\
\hline BIF & 0.086 & 0.045 & 0.068 & 0.202 \\
\hline TRL & 0.153 & -0.096 & 0.133 & 0.025 \\
\hline PL & 0.322 & -0.208 & 0.297 & -0.142 \\
\hline BPP & 0.151 & -0.056 & 0.143 & 0.320 \\
\hline ВРM3 & 0.128 & -0.216 & 0.129 & 0.160 \\
\hline TBL & 0.032 & 0.764 & 0.058 & 0.164 \\
\hline Eigenvalue & 28.368 & 0.928 & 14.572 & 0.956 \\
\hline$\%$ variance & 85.934 & 28.131 & 72.171 & 48.742 \\
\hline
\end{tabular}

(BIO1 and BIO4; Figure S3). On the other hand, latitude showed a strong positive correlation with precipitation seasonality (BIO15), while longitude was positively correlated with humidity and annual precipitation (BIO12) and to a lesser extent with NPP and annual temperature (BIO1). Humidity and NPP showed a strong positive correlation, and were both correlated with annual precipitation (BI012). Humidity, and to a lesser extent NPP, showed a negative correlation with temperature seasonality (BIO4). Finally, altitude was also negatively correlated with humidity, with both temperature variables (BIO1 and $\mathrm{BIO4}$ ), and with annual precipitation ( $\mathrm{BIO12}$ ).

\section{Geographical variation and environmental variables}

A significant spatial structure of the cranial size of $M$. australis ( $p$-value=0.02), was found, in which the geographic coordinates of the sampling sites explained $23.7 \%$ of cranial size variation. Individuals with the lowest geometric mean were found to the north, while individuals with the highest geometric mean were found to the south of the species distributional range (Figure 2). Similarly, at latitude $45^{\circ}$, individuals with the largest skull are found near the Atlantic coast.

The environmental variables significantly associated with skull size were annual temperature $(\mathrm{BIO1}, \mathrm{p}=0.009)$ and temperature seasonality $(\mathrm{BIO} 4, \mathrm{p}=0.005)$, which explained a $42.3 \%$ of the total variability. In the coldest sites, and in those with lower temperature seasonality (BIO4), individuals showed a larger geometric mean, while in opposite climatic situations, smaller individuals were found (Figure 3).

In the case of $M$. maenas, the spatial variation in its cranial morphology was less notorious in comparison with $M$. australis (Figure 2). The environmental variables that significantly explained its distributional range were annual temperature $(\mathrm{BIO1})(\mathrm{p}=0.03)$ and precipitation seasonality $(\mathrm{BIO15})(\mathrm{p}=0.02)$; the model that included these variables explained ca. $28 \%$ of the total variability. Microcavia maenas individuals with larger skulls were found in warmer sites with greater precipitation seasonality, while individuals with smaller skulls were found under the opposite climatic conditions (Figure 3). 

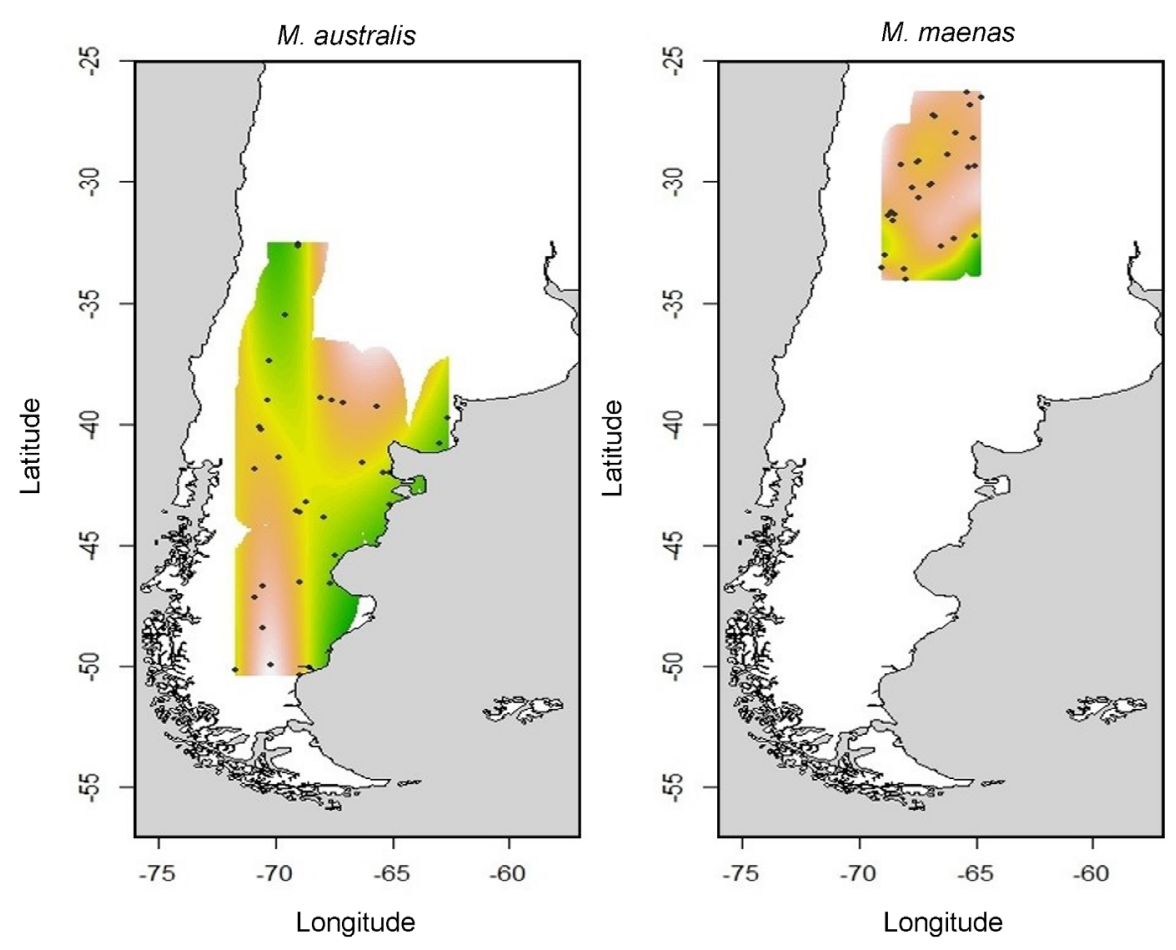

Figure 2. Generalized additive models (GAM) analyses in Microcavia australis (left) and $M$. maenas (right), evaluating the geometric mean in the geographic space. The gradient from green to red corresponds to increasing geometric mean.
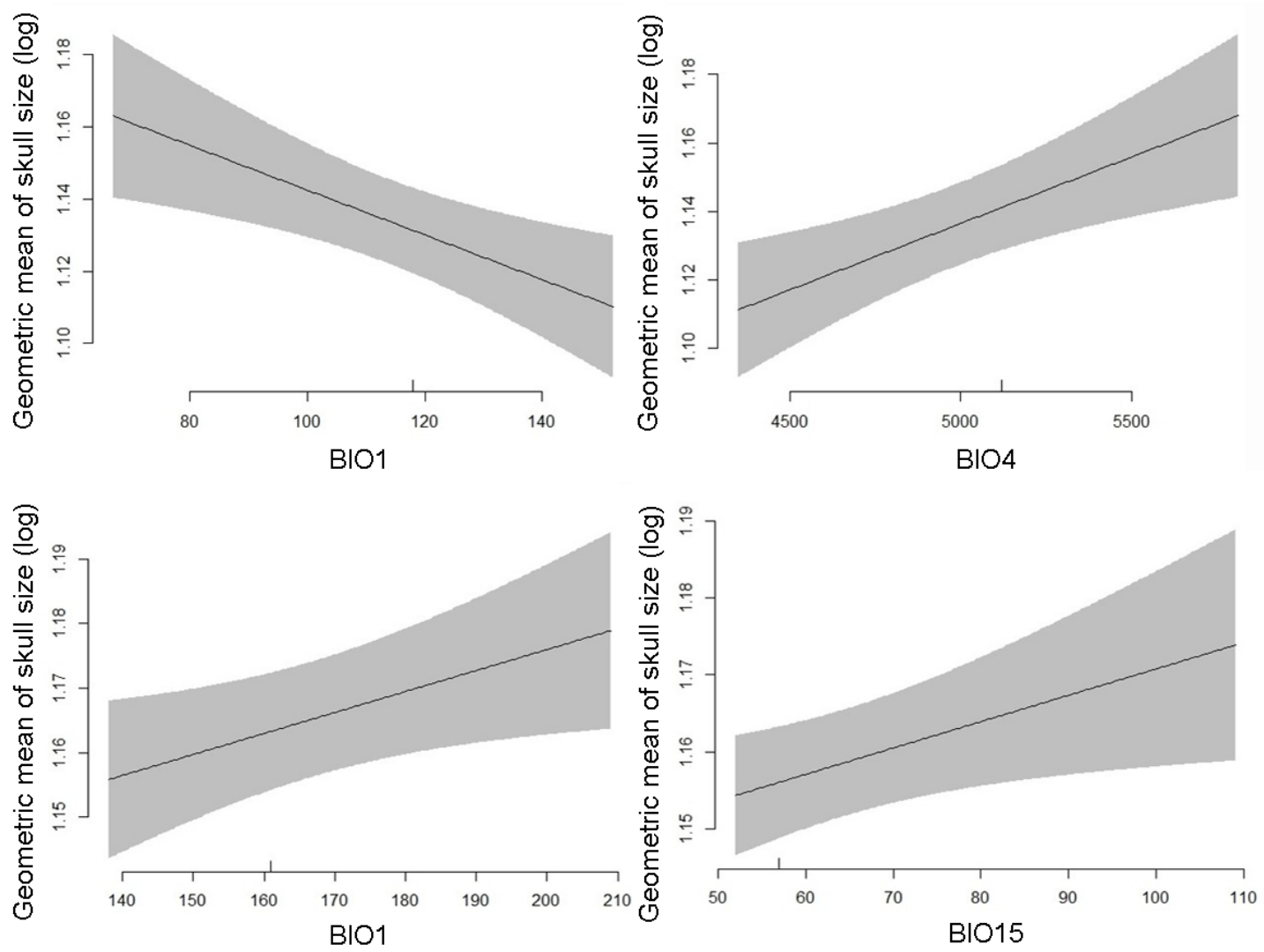

Figure 3. Variation of the geometric mean of skull size according to mean annual temperature (BIO1), temperature seasonality (BIO4) and precipitation seasonality (BIO15) in the geographic space of $M$. australis (above) and M. maenas (below). 


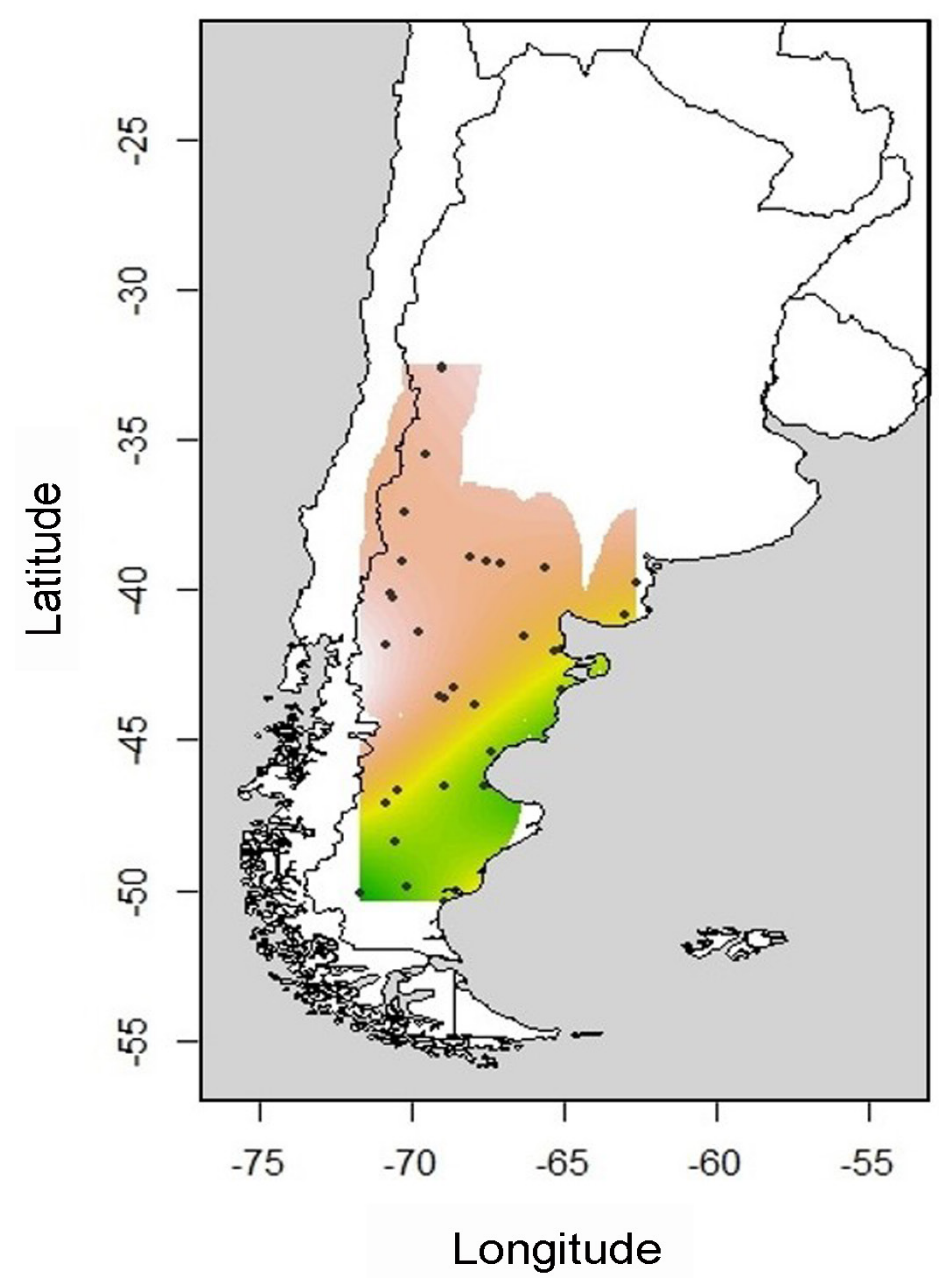

Figure 4. Generalized additive models (GAM) analyses of Microcavia australis, evaluating the tympanic bullae length (TBL) in the geographic space. The gradient from green to red corresponds to increasing geometric mean.

\section{Tympanic bullae length in M. australis}

Since the TBL showed a different behaviour to the rest of the morphological variables, with certain independence regarding cranial size, it was modeled separately. The spatial model explained a $56 \%$ of the total variability $(p=0.001)$, and it was observed that larger bullae were found towards the north, associated to smaller-sized skulls, while smaller bullae were found towards the south of its distribution, in association to larger-sized skulls (Figure 4). The variables that significantly explained tympanic bullae size were altitude standard deviation $(p=0.0006)$ and temperature seasonality $(p=0.0006)$. As expected, the tympanic bullae size increased as both temperature seasonality (BIO4), and altitude standard deviation increased (Figure 5).

\section{DISCUSSION}

According to our prediction, our results show that M. australis presented greater ecomorphological variability than M. maenas. However, both species showed a north-south clinal gradient of cranial size variation, which could be explained by the hypothesis that size is more prone to change due to environmental variations, while shape would be genetically controlled (Patton \& Brylski 1987, Cardini \& Elton 2009, Maestri et al. 2016). As previously stated, M. maenas distribution was much more geographically restricted than 

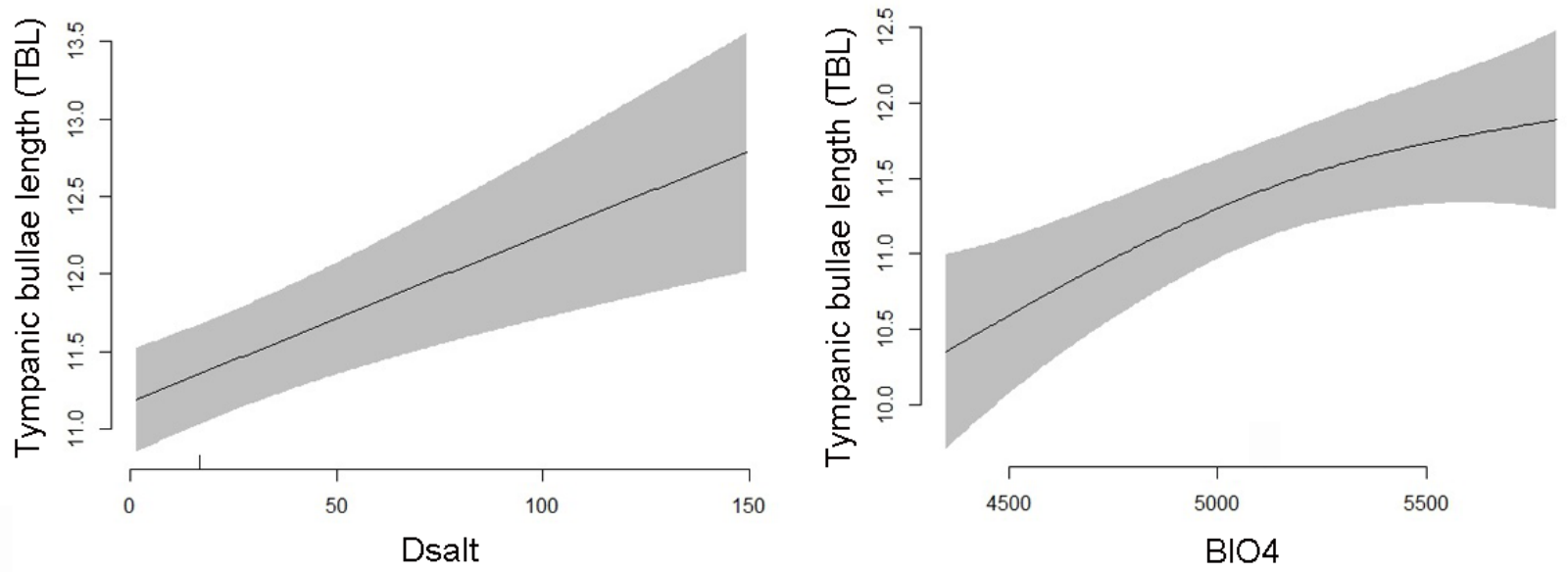

Figure 5. Variation of the tympanic bullae length (TBL) according to standard deviation altitude (DSalt, left) and seasonal temperature (BIO4, right) in the geographic space of Microcavia australis.

that of M. australis, thus the spatial variation in cranial morphology was much less notorious.

The cranial size of $M$. australis was conditioned both by annual temperature and temperature seasonality, being this variable a limiting factor mainly towards the southern portion of its distribution. In this species, individuals with a smaller cranial size (represented by the geometric mean), were found towards the north of its distribution area, where annual temperature is higher and seasonality is more marked, while largest individuals were found towards the south, in colder environments. On the one hand, M. australis, complied with the pattern established by the Bergmann's rule, and therefore with the heat conservation hypothesis. On the other hand, although productivity and humidity were not included in the statistical models due to their high correlation with other included variables in the matrix correlation (Figure S3), it can be observed that NPP is positively correlated with temperature. Thus, we verify that the environments inhabited by $M$. australis are mostly unproductive areas in terms of plant biomass, in which temperature acts as a limiting factor. Based on these same results, $M$. australis would comply with the hypothesis of heat dissipation, in which the higher relationship between surface/volume of the smallest individuals would facilitate heat dissipation in warm and humid environments, which occur mostly towards the north of its distribution area. The productivity hypothesis could not be directly tested, since as was mentioned, that variable did not enter into the models. However, although the hypothesis does not necessarily establish a positive relationship of NPP with the temperature (Wigginton \& Dobson 1999), we can assume that within the distribution range of M. australis, temperature plays a relevant role in the spatial patterns of body variation. The geographic distribution of $M$. australis include the High Andes, Espinal, Pampean, Patagonian Steppe and Low Monte ecoregions, all of them with relatively low productivity. Finally, regarding the seasonality hypothesis, individuals with larger skulls were found in environments with higher temperature seasonality.

In the case of $M$. maenas, the geographic variation in quantitative cranial traits was much less evident than in M. australis. This situation is consistent with its relatively reduced distribution range (occurs mostly in the High Monte ecoregion), and the homogeneity of the 
environmental variables within the geographical space occupied by this species. We therefore hypothesized that this species could not respond to the biogeographic rules mentioned above. However, it could be documented that individuals with greater cranial size were found in warm places with high rainfall seasonality, while those with smaller size were associated to places with lower temperatures. We consider that the biological significance of this pattern must be further assessed, for example by carrying out studies at a microgeographic scale (e.g., Le Boulengé et al. 1996).

In the case of $M$. australis, the individuals with larger tympanic bullae were found in areas with high temperatures (i.e., towards the north of its distribution, and associated with smaller skulls). Similarly, the bullae size increased together with the variation in altitude and temperature seasonality. It is worth remarking that, in mammals, several adaptive traits are attributed to living in desert environments, and the tympanic bullae size is one of such attributes (Schmidt-Nielsen \& Schmidt-Nielsen 1950, Lay 1972, Webster \& Webster 1975, Cortes et al. 1988, 1990, Ojeda et al. 1999). Lay (1972) found that as aridity increases, greater anatomical specialization of the middle and inner ear can be found, as consequence of greater hearing sensitivity. In other words, the enlargement of the tympanic bullae is described as an adaptation for capturing prey and/or avoiding predation in open environments, where sounds are easily dissipated, and where early detection is crucial to avoid predators (Lay 1972, Webster \& Webster 1975, Alhajeri \& Steppan 2018). Furthermore, many rodents inhabiting desert environments are fossorial, due to the low natural refuge supply offered by open habitats, thus greater sensibility to sound is important for underground vocalizations, which involve low frequency sounds (Lay 1972). This is the case of Microcavia that usually lives in caves under brushes.

Phenotypic responses to environmental conditions can result from genetic changes that might be adaptative, or part of the species genetic composition. Phenotypic plasticity should be the null hypothesis in studies addressing the relationship between phenotypic attributes and environmental factors (Merilä \& Hendry 2014, García-Mendoza et al. 2018). Both in $M$. australis, and to a lesser extent in $M$. maenas, phylogeographic analysis of molecular data could provide information on the genetic differentiation processes, and allow formulating hypotheses about the origins of the observed phenotypic variation.

\section{Acknowledgments}

We thank the curators and technicians from the following institutions: S. Lucero and G. Cassini (Museo Argentino de Ciencias Naturales "Bernardino Rivadavia"); R. Barquez, and M. M. Díaz (Colección de Mamíferos de la Facultad de Ciencias Naturales e Instituto Miguel Lillo); B. Bender, and R. Ojeda (Colección de Mamíferos del Instituto Argentino de Investigación de Zonas Áridas); S. Bogan (Colección de Mamíferos Fundación Félix de Azara); U.F. J. Pardiñas (Colección de Mamíferos del Centro Nacional Patagónico); G.D’ Elia (Colección de Mamíferos de la Universidad Austral de Chile); B. O'Toole, N. Simmons, and R. Voss (American Museum of Natural History); B. Patterson (Field Museum of Natural History); D. Lunde (United States Natural Museum). We are also grateful with G. Cassini and Fabio Machado, who helped us with the interpretation and discussion of the results.

\section{REFERENCES}

ALDRICH JW \& JAMES FC. 1991. Ecogeographic variation in the American robin (Turdus migratorius). Auk 108: 230-249.

ALHAJERI BH \& STEPPAN SJ. 2018. A phylogenetic test of adaptation to deserts and aridity in skull and dental morphology across rodents. J Mammal 99: 1197-1216.

ALVARADO-SERRANO DF, LUNA L \& KNOWLES LL. 2013. Localized versus generalist phenotypes in a broadly distributed tropical mammal: how is intraspecific variation 
distributed across disparate environments? BMC Evol Biol 13: 160.

ÁVILA-VALLE ZA, CASTRO-CAMPILLO A, LEÓN-PANIAGUA L, SALGADO-UGALDE IH, NAVARRO-SIGÜENZA AG, HERNÁNDEZBANOS BE \& RAMÍREZ-PULIDO J. 2012. Geographic variation and molecular evidence of the Blackish Deer Mouse complex (Peromyscus furvus, Rodentia: Muridae). Mammal Biol 77: 166-177.

BERGMANN C. 1847. Ueber die verhältnisse der wärmeökonomie der thiere zu ihrer grösse. Gottingen Studien 1: 595-708.

BOYCE MS. 1978. Climatic variability and body size variation in the muskrats (Ondatra zibethicus) of North America. Oecologia 36: 1-19.

BOYCE MS. 1979. Seasonality and patterns of natural selection for life histories. Am Nat 114: 569-583.

BRADLEY RD, OWEN RD \& SCHMIDLY DJ. 1996. Morphological variation in Peromyscus spicilegus. Occas Pap Tex Tech Univ Mus 159: 1-23.

BROWN JH \& LEE AK. 1969. Bergmann's rule and climatic adaptation in woodrats (Neotoma). Evolution 23: 329-338.

CARDINI A \& ELTON S. 2009. Geographical and taxonomic influences on cranial variation in red colobus monkeys (Primates, Colobinae): introducing a new approach to 'morph' monkeys. Glob Ecol Biogeogr 18: 248-263.

CONTRERAS JR \& CONTRERAS ANC. 1984. Craneología y craneometría del género Ctenomys. II. Craneometría. Hist Nat 4: 245-248.

CORTES A, ROSENMANN M \& BÁEZ C. 1990. Función del riñón y del pasaje nasal en la conservación de agua corporal en roedores simpátridos de Chile central. Rev Chil Hist Nat 63: 279-291.

CORTES A, ZULETA C \& ROSENMANN M. 1988. Comparative water economy of sympatric rodents in a Chilean semiarid habitat. Comp Biochem Physiol A 9: 711-714.

DUNBRACK RL \& RAMSAY MA. 1993. The allometry of mammalian adaptations to seasonal environments: a critique of the fasting endurance hypothesis. Oikos 66: 336-342.

ENDLER JA. 1983. Testing causal hypotheses in the study of geographic variation. In: Felsenstein J (Ed). Numerical taxonomy, Springer, Berlin, Heidelberg, p. 424-443.

GARCÍA E. 1988. Modificaciones al sistema de clasificación climática de Köppen. $4^{\text {th }}$ ed., UNAM, México, DF, 217 p.

GARCÍA-MENDOZA DF, LÓPEZ-GONZÁLEZ C, HORTELANOMONCADA Y, LÓPEZ-WILCHIS R \& ORTEGA J. 2018. Geographic cranial variation in Peromyscus melanotis (Rodentia: Cricetidae) is related to primary productivity. J Mammal 99: 898-9059.

GÜR H. 2010. Why do Anatolian ground squirrels exhibit a Bergmannian size pattern? A phylogenetic comparative analysis of geographic variation in body size. Biol J Linn Soc Lond 100: 695-710.

HAMMER Ф, HARPER DAT \& RYAN PD. 2001. PAST: Paleontological statistics software package for education and data analysis. Palaeontol Electronica 4: 9.

HIJMANS RJ, CAMERON SE, PARRA JL, JONES PG \& JARVIS A. 2005. Very high resolution interpolated climate surfaces for global land areas. Int J Climatol 25: 1965-1978.

HOFFMEISTER DF. 1951. A taxonomic and evolutionary study of the piñon mouse, Peromyscus truei. Illinois Biological Monographs 21: 1-104.

JAMES FC. 1970. Geographic size variation in birds and its relationship to climate. Ecology 51: 365-390.

JAMES FC. 1991. Complementary descriptive and experimental studies of clinal variation in birds. Am Zool 31: 694-706.

KENNEDY ML \& LINDSAY SL. 1984. Morphologic variation in the raccoon, Procyon lotor, and its relationship to genic and environmental variation. J Mammal 65: 195-205.

LANG S \& FAHRMEIR L. 2001. Bayesian generalized additive mixed models, a simulation study. J R Stat Soc Ser C Appl Stat 50: 201-220.

LAY DM. 1972. The anatomy, physiology, functional significance and evolution of specialized hearing organs of Gerbillinae rodents. J Morph 138: 41-120.

LE BOULENGÉ É, LEGENDRE P, DE LE COURT C, LE BOULENGÉNGUYEN P \& LANGUY M. 1996. Microgeographic morphological differentiation in muskrats. J Mammal 77: 684-701.

LINDSTEDT SL \& BOYCE MS. 1985. Seasonality, fasting endurance, and body size in mammals. Am Nat 125: 873-878.

LORENZO C, ÁLVAREZ-CASTAÑEDA ST, PÉREZ-CONSUEGRA SG \& PATTON JL. 2016. Revision of the Chiapan deer mouse, Peromyscus zarhynchus, with the description of a new species. J Mammal 97: 910-918.

MAESTRI R, FORNEL R, GONÇALVES GL, GEISE L, DE FREITAS TRO \& CARNAVAL AC. 2016. Predictors of intraspecific morphological variability in a tropical hotspot: comparing the influence of random and non-random factors. J Biogeogr 43: 2160-2172. 
MARTÍNEZ PA, MARTI DA, MOLINA WF \& BIDAU CJ. 2013. Bergmann's rule across the equator: a case study in Cerdocyon thous (Canidae). J Anim Ecol 82: 997-1008.

MAYR E. 1956. Geographical character gradients and climatic adaptation. Evolution 10: 105-108.

MAYR E. 1963. Animal species and evolution. Harvard University Press, Cambridge, Massachusetts, USA.

MCGUIRE JL. 2010. Geometric morphometrics of vole (Microtus californicus) dentition as a new palaeoclimate proxy: shape change along geographic and climatic clines. Quat Int 212: 198-205.

MCNAB BK. 1971. On the ecological significance of Bergmann's rule. Ecology 52: 845-854.

MCNAB BK. 2002. Minimizing energy expenditure facilitates vertebrate persistence on oceanic islands. Ecol Lett 5: 693-704.

MCNAB BK. 2010. Geographic and temporal correlations of mammalian size reconsidered: a resource rule. Oecologia 164: 13-23.

MEACHEN-SAMUELS J \& VAN VALKENBURGH B. 2009. Craniodental indicators of prey size preference in the Felidae. Biol J Linn Soc Lond 96: 784-799.

MERILÄ J \& HENDRY AP. 2014. Climate change, adaptation, and phenotypic plasticity: the problem and the evidence. Evol Appl 7: 1-14.

MILLAR JS \& HICKLING GJ. 1990. Fasting endurance and the evolution of mammalian body size. Funct Ecol 4: 5-12.

MONTEIRO L, DUARTE LC \& DOS REIS SF. 2003. Environmental correlates of geographical variation in skull and mandible shape of the punaré rat Thrichomys apereoides (Rodentia: Echimyidae). J Zool 261: 47-57.

MOSIMANN JE. 1970. Size allometry: size and shape variables with characterizations of the lognormal and generalized gamma distributions. J Am Stat Assoc 65: 930-945.

OJEDA RA, BORGHI CE, DIAZ GB, GIANNONI SM, MARES MA \& BRAUN JK. 1999. Evolutionary convergence of the highly adapted desert rodent Tympanoctomys barrerae (Octodontidae). J Arid Environ 41: 443-452.

ORDÓÑEZ-GARZA N, MATSON JO, STRAUSS RE, BRADLEY RD \& SALAZAR-BRAVO J. 2010. Patterns of phenotypic and genetic variation in three species of endemic Mesoamerican Peromyscus (Rodentia: Cricetidae). J Mammal 91: 848-859.

OWEN JG. 1989. Population and geographic variation of Peromyscus leucopus in relation to climatic factors. J Mammal 70: 98-109.
PATTON JL \& BRYLSKI PV. 1987. Pocket gophers in alfalfa fields: causes and consequences of habitat-related body size variation. Am Nat 130: 493-506.

PEREZ SI, DINIZ-FILHO JAF, BERNAL V \& GONZALEZ PN. 2010. Spatial regression techniques for inter-population data: studying the relationships between morphological and environmental variation. J Evol Biol 23: 237-248.

PEREZ SI \& MONTEIRO LR. 2008. Nonrandom factors in modern human morphological diversification: a study of craniofacial variation in southern south American populations. Evolution 64: 978-993.

R CORE TEAM. 2017. R: A language and environment for statistical computing. Vienna, Austria: R Foundation for Statistical Computing.

RALLS K \& HARVEY PH. 1985. Geographic variation in size and sexual dimorphism of North American weasels. Biol J Linn Soc 25: 119-167.

RENSCH B. 1938. Some problems of geographical variation and species-formation. Proc Linn Soc Lond 150: 275-285.

RITKE ME \& KENNEDY ML. 1988. Intraspecific morphologic variation in the raccoon (Procyon lotor) and its relationship to selected environmental variables. Southwest Nat 33: 295-314.

ROSENZWEIG ML. 1968a. The strategy of body size in mammalian carnivores. Am Midl Nat 80: 299-315.

ROSENZWEIG ML. 1968b. Net primary productivity of terrestrial communities: prediction from climatological data. Am Nat 102: 67-74.

SCHMIDLY DJ. 1973. Geographic variation and taxonomy of Peromyscus boylii from Mexico and the southern United States. J Mammal 54: 111-130.

SCHMIDT-NIELSEN B \& SCHMIDT-NIELSEN K. 1950. Pulmonary water loss in desert rodents. Am J Physiol 162: 31-36.

SIKES RS \& KENNEDY ML. 1992. Morphologic variation of the bobcat (Felis rufus) in the eastern United States and its association with selected environmental variables. Am Midl Nat 128: 313-324.

TETA P, OJEDA RA, LUCERO SO \& D'ELÍA G. 2017. Geographic Variation in Cranial Morphology of the Southern Mountain Cavy, Microcavia australis (Rodentia, Caviidae): Taxonomic Implications, with the Description of a New Species. Zool Stud 56: 29.

THORPE RS. 1984. Primary and secondary transition zones in speciation and population differentiation: a phylogenetic analysis of range expansion. Evolution 38: 233-243. 
THORPE RS. 1987. Geographic variation: a synthesis of cause, data, pattern and congruence in relation to subspecies, multivariate analysis and phylogenesis. Ital J Zool 54: 3-11.

UBILLA M \& RINDERKNECHT A. 2014. Comparative analysis of Galea (Rodentia, Caviidae) and expanded diagnosis of Galea ortodonta Ubilla \& Rinderknecht, 2001 (Late Pleistocene, Uruguay). Geobios 47: 255-269.

WEBSTER D \& WEBSTER M. 1975. Auditory systems of Heteromyidae: functional morphology and evolution of the middle ear. J Morph 146: 343-376.

WEI T \& SIMKO V. 2016. corrplot: Visualization of a Correlation Matrix. R package version 0.77.

WIGGINTON JD \& DOBSON FS. 1999. Environmental influences on geographic variation in body size of western bobcats. Can J of Zool 77: 802-813.

WOOD SM. 2016. Just Another Gibbs Additive Modeler: Interfacing JAGS and mgcv. J Stat Softw 75: 1-15.

WOOD SN. 2017. Generalized Additive Models: An Introduction with R. Chapman and Hall/CRC.

\section{Appendix A. List of studied specimens.}

Institutional Acronyms: MACN: Museo Argentino de Ciencias Naturales "Bernardino Rivadavia"; CML: Colección de Mamíferos de la Facultad de Ciencias Naturales e Instituto Miguel Lillo; CMI: Colección de Mamíferos del Instituto Argentino de Investigación de Zonas Áridas; CEM: Colección Elio Massoia; CNP: Colección de Mamíferos del Centro Nacional Patagónico; UACh: Colección de Mamíferos de la Universidad Austral de Chile; AMNH: American Museum of Natural History; FMNH: Field Museum Natural History; UCNM: United States Natural Museum.

Microcavia australis: MACN: 15.4; 28.50; 35.62; 35.57; 13467; 13935; 14527; 14531; 14543; 14586; 16379; 26171; 26201; 26200; 26202; 28150; 28153; 33229; 33230. CML: 1441; 1442; 1446; 1447. CMI: 2453; 2454; 2457; 2464; 2465; 2481; 6593; 7230; 7231; 7236. CNP: 132; 146; 166; 905; 921; 950; 963; 977; 1011; 1200; 1031; 1034; 1043; 1059; 1062; 1749; 2116; 2169. AMNH: 14285; 25713; 25714; 25715; 25717. FMNH: 28502; 28503; 28504; 29071; 23839; 23300; 124494; 124495; 124497; 124498. NMHN: 236337; 236338;
236339; 236340. NHNM: 49517; 84180; 84181; 84182; 84170; 84177.

Microcavia maenas: MACN: 323; 25.36; 29.12; 29.13; 29.15; 29.48; 34.27; 34.28; 34.31; 34.32; 34.42; 34.47 ; 34.48; 34.49; 34.52; 34.54; 34.56; 34.57; 34.58; $34.65 ; 34.66 ; 34.70 ; 34.79 ; 34.80 ; 34.81 ; 34.92 ; 34.93$; 34.94; 36.72; 36.84; 13123; 13124; 13758; 13777; 13778; 26213; 26214; 34115; 34116; 34120; 34121; 34135; 34137; 34146; 34149; 34159; 34161; 34165; 34170; 34184; 42323; 42326; 54102. CML: 843; 888; 1010; 1012; 1102; 1144; 1154; 1155; 1159; 1169; 1174; 1394; 2360; 6841; 7238. CMI: 2475; 3796; 5890; 6248; 6250; 6594; 6596; 6597; 6599; 6600; 6986; 7064; 7066; 7067; 7068; 7069; 7071; 7209; 7211; 7240; 7304. CEM: 4201. AMNH: 4162; 41563; 41564; 41566; 41567; 41895. UACH: 6169; 6171; 6173; 6174; 6175; 6176

\section{Appendix B. Gazetteer of localities. Numbers refer to localities depicted in Figure 1.}

Microcavia australis: Mendoza: 1- Villavicencio (-32.53 S, -69.02 W). 2- Malargue (-35.48 S, -69.58 W). 3- Quebrada del Toro, Las Heras (-32.63 S, 69.03 W). Buenos Aires: 3- Igarzabal (-39.77 S, -62. 62 W). 4- Patagones (-40.80 S, -63.00 W). Neuquén: 5Neuquén (-38.93 S, -68.06 W). 6- Parque Nacional Laguna Blanca (-39.03 S, -70.32 W). 7- Estancia Yuncón, Collón Cura (-40.13 S, -70.67 W). 8- Valle del Río Collón Cura, Cerrito Piñón, Collón Cura (-40.23 S, -70.62 W). 9- Chosmalal (-37.38 S, -70.27 W). Río Negro: 10- Choele Choel, Avellaneda (-39.27 S, -65.65 W). 11- Norquinco (-41.83 S, -70.90 W). 12- Villa Regina, General Roca (-39.10 S, -67.07 W). 13- Campana Mahuida, Loncopue (-41.57 S, -66.30 W). 14- Huanuluan (-41.37 S, -69.81 W). 15- General Roca (-39.03 S, -67.58 W). Chubut: 16- Ruta Provincial N²5 km 347 (-43.86 S, -67.95 W). 17- Campo de Pichiñan (-43.56 S, -69.07 W). 18- Estancia La Porfia (-43.23 S, -68.65 W). 19Pico Salamanca (-45.41 S, -67.42 W). 20- Estancia La Madrugada (-43.63 S, -68.95 W). 21- Rawson (-43.30 S, -65.10 W). 22- Puerto Lobos (-42.00 S, -65.08 W). 23- Arroyo Verde (-42.01 S, -65.35 W). 
Santa Cruz: 24- Ruta 40 entre el Lago Viedma y el Lago Argentino (-50.02 S, -68.52 W). 25- $18 \mathrm{~km}$ al S de Caleta Olivia (-46.55 S, -67.63 W). 26- Estancia El Tranquilo, $250 \mathrm{~km}$ al S de las Heras (-50.13 S, -71.68 W). 27- Estancia Roca Blanca, 250 km al $\mathrm{S}$ de las Heras (-46.53 S, -68.95 W). 28- Arroyo Aique (-46.67 S, -70.50 W). 29- Paso Ibáñez (-49.91 S, -70.20 W). 30- Río Ecker (= Arroyo Eke) (-47.13 S, -70.86 W). 31- Cerro Observación (-50.86 S, -69.09 W). 32- Patagonia, Upper Río Chico (-48.40 S, -70.55 W).

Microcavia maenas: Tucumán: 33- Tucumán (-26.82 S, -65.22 W). 34- Villa Burruyacú, Burruyacú (-26.50 S, -64.74 W). 35- Agua Rosada, Trancas (-26.28 S, -65.4 W). Catamarca: 36- Nuestra Señora de La Paz, La Par (-29.42 S, -65.28 W). 37- Recreo, La Paz (-29.36 S, -65.06 W). 38- Chumbicha, Capayán (-28.85 S, -66.23 W). 39- Hualfín (-27.23 S, -66.86 W). 40- 5,2 km de El Bolsón, Belén (-27.96 S, -65.85 W). 41- Agua de Dionisio, Hualfín (-27.27 S, -66.72 W) Santiago del Estero: 42- Lavalle (-28.2 S, -65.13 W). La Rioja: 43- Tilimuqui, Chilecito (-29.13 S, -67.41 W). 44- Patquía, Independencia (-30.13 S, -66.95 W). 45- Villa Unión (-29.3 S, -68.2 W). 46- Chilecito (-29.16 S, -67.5 W). 47- Guayapa (-30.06 S, -66.88 W). San Juan: 48- Valle Fértil (-30.66 S, -67.43 W). 49- Ullún, Matagusanos (-31.24 S, -68.62 W). 50La Laja (-31.35 S, -68.46 W). 51- Ullún (-31.41 S, -68.73 W). 52- Los Baldecitos, Valle Fértil (-30.22 S, -67.69 W). 53- Angaco Sud (-31.58 S, -68.55 W) Córdoba: 54- La Paz, San Javier (-32.21 S, -65.04 W). Mendoza: 55- Chacras de Coria, Luján de Cuyo (-33.01 S, -98.89 W). 56- Reserva Ñacuñan (-34.03 S, -67.96 W). 57- Pichi Ciego (-33.58 S, -68.06 W). 58- Tunuyán (-33.56 S, -69.01 W). San Luis: 59Villa General Roca, Belgrano (-32.66 S, -66.45 W). 60- Luján (-32.36 S, -65.95 W).

\section{SUPPLEMENTARY MATERIAL}

\section{Figures S1, S2 and S3.}

\section{How to cite}

D' HIRIAR S, TETA P \& CUETO GR. 2021. Geographic patterns of skull variation in two species of cavies of the genus Microcavia (Rodentia, Caviidae.). An Acad Bras Cienc 93: e20190429. DOI 10.1590/00013765202120190429.

\section{Manuscript received on April 10, 2019;}

accepted for publication on July 8, 2019

\section{SOFÍA d' HIRIART ${ }^{1}$}

https://orcid.org/0000-0002-5238-1058

\section{PABLO TETA ${ }^{1}$}

https://orcid.org/0000-0001-8694-0498

\section{GERARDO R. CUETO ${ }^{2}$}

https://orcid.org/0000-0001-8230-8874

${ }^{1}$ División Mastozoología, Museo Argentino de Ciencias Naturales "Bernardino Rivadavia", Avenida Ángel Gallardo 470, (C1405DJR) Buenos Aires, Argentina

${ }^{2}$ Departamento de Ecología, Genética y Evolución, Instituto IEGEBA (CONICET-UBA), Facultad de Ciencias Exactas y Naturales, Universidad de Buenos Aires, Intendente Guiraldes 2160, (C1428EGA) Ciudad Universitaria, Ciudad Autónoma de Buenos Aires, Argentina

Correspondence to: Sofía d' Hiriart

E-mail:sofiadiriart@gmail.com

\section{Author contributions}

PT and Sd'H conceived the idea. PT reviewed the specimens housed at biological collections. GC carried out the analysis of data. Sd'H prepared the tables and figures, and wrote a draft of the manuscript. All the authors discussed and interpreted the results and approved the final version of the manuscript.

\section{(cc) $\mathbf{B Y}$}

